\title{
DYNAMIC YOUNG'S MODULUS, MORPHOLOGICAL, AND THERMAL STABILITY OF 5 TROPICAL LIGHT HARDWOODS MODIFIED BY BENZENE DIAZONIUM SALT TREATMENT
}

\author{
Md. Saiful Islam, ${ }^{\text {a* }}$ Sinin Hamdan, ${ }^{\text {a }}$ Md. Rezaur Rahman, ${ }^{a}$ I. Jusoh, ${ }^{b}$ Abu Saleh Ahmed, ${ }^{a}$ \\ and Mun'aim Idrus ${ }^{\text {a }}$ \\ In this study the tropical light hardwood species jelutong (Dyera \\ costulata), terbulan (Endospermum diadenum), batai (Paraserianthes \\ moluccana), rubberwood (Hevea brasiliensis), and pulai (Alstonia \\ pneumatophora) were treated with benzene diazonium salt to improve \\ their dynamic Young's modulus $\left(E_{d}\right)$, and thermal stability. Benzine \\ diazonium salt reacted with cellulose in wood and produced 2,6- \\ diazocellulose by a coupling reaction, as confirmed by Fourier transform \\ infrared (FTIR) spectroscopy. Values of $E_{d}$ were calculated from the free- \\ free flexural vibration method and found to increase on treatment. The \\ morphological properties were studied by FTIR and scanning electron \\ microscopy (SEM) and found to be changed. Thermal properties of \\ treated wood samples were evaluated by thermogravimetric analysis \\ (TGA) and differential scanning calorimetry (DSC). The treated wood \\ samples exhibited an increased thermal stability relative to the untreated \\ wood samples; this increase may be related to the formation of 2, 6- \\ diazo cellulose compound.
}

Keywords: Dynamic Young's modulus; Thermal stability; FTIR; Tropical wood

Contact information: a: Department of Mechanical and Manufacturing Engineering, Faculty of Engineering; b: Department of Plant Science and Environmental Ecology, Faculty of Resources Science, Universiti Malaysia Sarawak, 94300 Kota Samarahan, Malaysia. *Corresponding author: msaifuli2007@gmail.com.

\section{INTRODUCTION}

Wood is a renewable resource and one of the most fascinating materials because of its complex structure and wide application on earth. Solid wood is a preferred building and construction material due to its physical, mechanical, and very aesthetically pleasing performances. But wood has some drawbacks: its physical and chemical properties readily are changed through environmental factors such as light, water, temperature, and biological organisms, which are the main limits for its outdoors and indoors application (Yalinkilic et al. 1999; Chao et al. 2003; Brelid et al. 2000; Deka et al. 2002). These inherent defects have primarily been ascribed to the presence of hydroxyl groups $(-\mathrm{OH})$ in the three major wood components, namely cellulose, hemicelluloses, and lignin. The hydroxyl groups attract water molecules from the surrounding environment for hydrogen bonding, causing swelling, and changing the physical, chemical, and thermal properties of wood. These effects are especially pronounced in tropical areas, where wood suffers from exposure to sunlight and high hygroscopicity, causing swelling and deformation. 
Changes to the physical, chemical, and thermal properties of wood due to environmental influences can be minimized by suitable chemical treatment, which is a promising way to improve wood properties (Schneider 1994; Hartley et al. 1993; Rowell 2005).

Wood has been treated with a variety of chemicals for several hundred years. These chemicals include anhydrides such as phthalic, succinic, maleic, propionic, and butyric anhydride, acid chlorides, ketene carboxylic acids, many different types of isocyanates, formaldehyde, several types of monomers such as styrene, epoxy resins, urethane, phenol formaldehyde, methyl methacrylate (MMA), vinyl or acrylic monomers, and so on (Hill 2006; Holyle et al. 1989; Rowell 2006). Some modification chemicals do not react with cell wall polymers in a so-called substitution reaction (Elvy et al. 1995). Many polymers, even though formed in situ, only fill the empty lumens in the wood, which leads to a mixture of two materials rather than a real interaction. Benzene diazonium salt has widely been used to reduce hydrophilicity of raw fibers in composites manufacturing (Haque et al 2009; Rahman et al. 2009). It has also been established that benzene diazonium salt yields diazo cellulose compound by the coupling reaction with $-\mathrm{OH}$ groups of cellulose fiber. However, in the literature most of the coupling reaction studies were performed on raw fiber such as jute, coir, abaca etc., while there was no work carried out on solid wood modification using diazonium salt. Also, little work has been devoted to Malaysian tropical wood species and their chemical modification (Yap et al. 1990).

The free-free flexural vibration method is a powerful technique to investigate the dynamic Young's modulus $(E \mathrm{~d})$ of wood. The vibration technique is among the nondestructive testing (NDT) methods that are considered important in the timber industry (Halabe et al. 1995). This technique is an alternative for measuring the elastic properties and energy dissipation of wood. The methods involves three types of vibration, namely bending (flexural), longitudinal (axial), and torsion, which are determined by the nature of vibration. Among the three types of vibration methods, the flexural vibration method is the most popular, since it is easiest to excite and detect the vibrations under investigation.

In the present work, five Malaysian tropical light hardwood species- jelutong, terbulan, batai, rubberwood, and pulai- were used for modification. The extreme growing shortage and rising costs of the heavy hardwoods has created interest in the utilization of lower grade woods such as tropical light hardwoods, whose usage can be extended by chemically modifying them into good quality. The major problems of using these species are their high moisture uptake, thermal instability, physical, and mechanical property changes with environmental variations, which limit their use (Kumar et al. 1994; Galpperin et al. 1995).

In order to change these problems and to increase their mechanical, thermal, and morphological properties, all wood species were chemically treated with benzene diazonium salt for the formation of diazo cellulose compound in the wood fiber. Thus, the main objectives of the present research are to develop the coupling reaction with tropical light hardwood species and investigate their dynamic Young's modulus, thermal stability, and morphological properties. 


\section{EXPERIMENTAL}

\section{Materials}

Five kinds of tropical light hard woods species namely jelutong (Dyera costulata), terbulan (Endospermum diadenum), batai (Paraserianthes moluccana), rubberwood (Hevea brasiliensis), and pulai (Alstonia pneumatophora) were collected from the local forest of Sarawak, Malaysia. Three trees per wood species were felled and cut into three bolts of $1.2 \mathrm{~m}$ length. Chemicals used for synthesis of benzene diazonium salt were aniline, sodium nitrite, and hydrochloric acid. Treatment of wood species was performed using a benzene diazonium salt solution containing sodium hydroxide. All chemicals were analytical reagent grade products of Merck, Germany.

\section{Synthesis of Benzene Diazonium Salt}

Benzene diazonium salt was synthesized in the laboratory with aniline and sodium nitrite in the presence of a mineral acid at $0^{\circ} \mathrm{C}$ to $5^{\circ} \mathrm{C}$ using the standard diazotization method (Ismail et al. 2002). The solution of phenylamine (aniline) in hydrochloric acid (phenylammonium chloride solution) is usually stored in a beaker of ice. The sodium nitrite solution is also cooled in the ice. The solution of the nitrite is then added very slowly to the phenylammonium chloride solution - so that the temperature never goes above $5^{\circ} \mathrm{C}$. The reaction scheme for synthesis of benzene diazonium salt is shown in Fig. 1. The solution containing diazonium salt was used very quickly in the coupling reaction with the wood species.

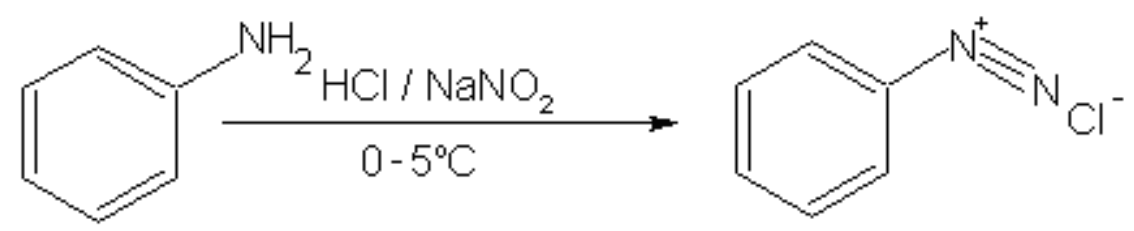

Fig. 1. The reaction scheme for synthesis of benzene diazonium salt

\section{Specimen Preparation}

As noted, three trees per wood species were felled and cut into three bolts of 1.2 $\mathrm{m}$ length. Each part was quarter sawn to produce planks of $4 \mathrm{~cm}$ thickness. Then they were subsequently conditioned to air-dry in a room with relative humidity of $60 \%$ and ambient temperature of $25^{\circ} \mathrm{C}$ for one month prior to testing. The planks were ripped and sized to $340 \mathrm{~mm}(\mathrm{~L}) \times 20 \mathrm{~mm}(\mathrm{~T}) \times 10 \mathrm{~mm}(\mathrm{R})$ specimen for the free-free vibration test and ground powder sample for TGA and DSC test respectively. Ten samples were used per test.

\section{Coupling Reaction/ Treatment of Wood Specimens}

The reaction of benzene diazonium salt with cellulose or cellulose derivatives is known as the coupling reaction (Ibrahim 2002). All oven-dried raw wood specimens were submersed in a benzene diazonium salt solution (kept $5^{\circ} \mathrm{C}$ ) containing $5 \mathrm{~L}$ of $\mathrm{NaOH}$ $5 \%$ solution in a reaction vessel for $30 \mathrm{~min}$ at ambient pressure. Specimens were then 
removed and soaked in cold acetone to quench the reaction. Chemically modified wood species were subsequently extracted with acetone:toluene $(1: 1)$ to remove unreacted reagents and oven dried at $105^{\circ} \mathrm{C}$ for 24 hours. The weight percentage gains (WPG) of the samples were then measured using the equation 1 ,

$$
W P G(\%)=\left[\left(W i-W_{o}\right) / W_{o}\right] \times 100
$$

where $W_{o}$ and $W i$ are oven-dried weight of untreated and treated wood samples, respectively.

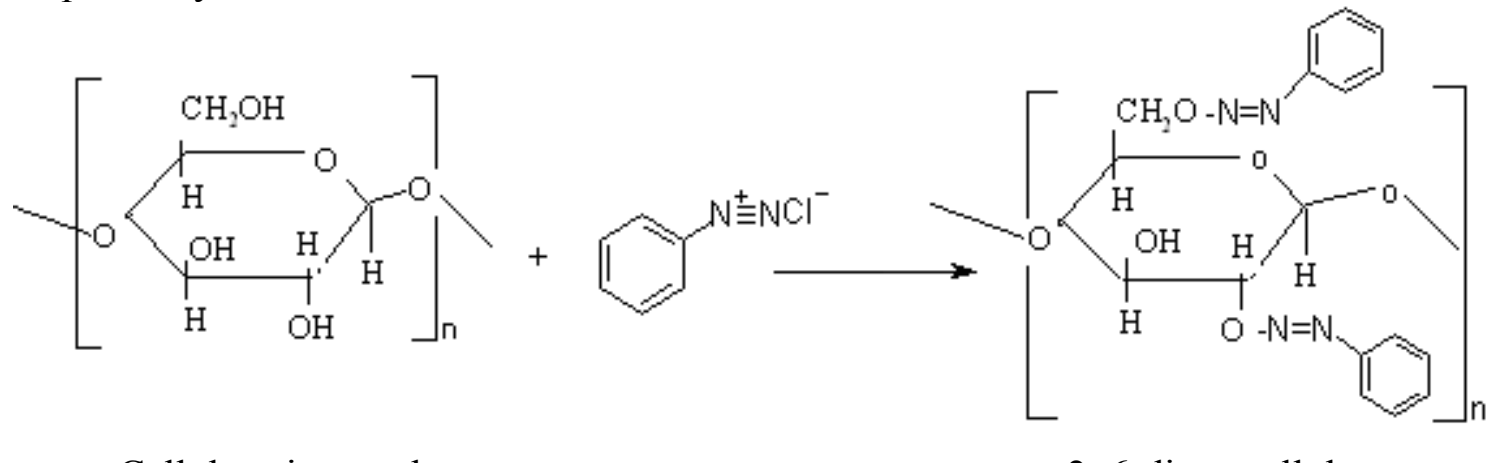

Cellulose in wood

2, 6-diazo cellulose

Fig. 2. Coupling reaction of benzene diazonium salt with cellulose unit

\section{Morphology Analysis}

Fourier Transform Infrared Spectroscopy (FTIR)

The infrared spectra of the untreated and treated grounded powder wood samples were recorded on a Shimadzu Fourier Transform Infrared Spectroscopy (FTIR) 81001 Spectrophotometer. The transmittance range of scan was 370 to $4000 \mathrm{~cm}^{-1}$.

\section{Scanning Electron Microscopy (SEM)}

The interfacial bonding between the cell wall polymer and reacted chemical were examined using a Scanning Electron Microscope (SEM) (JSM-6701F) supplied by JEOL Company Limited, Japan. The specimens were first fixed with Karnovsky's fixative and then taken through a graded alcohol dehydration series. Once dehydrated, the specimen was coated with a thin layer of gold before viewing on the SEM. The micrographs, taken at a magnification of $1000 \mathrm{x}$ and 2000x, are presented in the Results and Discussion section.

\section{Dynamic Young's Modulus (Ed) Measurement}

Dynamic Young's modulus $\left(\mathrm{E}_{\mathrm{d}}\right)$ was measured using the free-free flexural vibration testing system, and the details of this test can be obtained from references Islam and Hamdan (Islam et al. 2010; Hamdan et al. 2010). The $E_{d}$ was calculated from the resonant frequency by using the following equation,

$$
E_{d}=4 \pi^{2} f^{2} l^{4} A \rho / I\left(m_{n}\right)^{4}
$$


where $I=b d^{3} / 12, d$ is beam depth, $b$ is beam width, $l$ is beam length, $f$ is natural frequency of the specimen, $\rho$ is density, $A$ is the cross sectional area, $n$ is mode of vibration, and $m_{l}=4.730$.

\section{Thermal Analysis}

Thermogravimetric Analysis (TGA)

Thermogravimetric analysis (TGA) measurements were carried out on 5-10 mg of treated and untreated ground powder samples at a heating rate of $10^{\circ} \mathrm{C} / \mathrm{min}$ in a nitrogen atmosphere using a Thermogravimetric Analyzer (TA Instrument SDT Q600). Treated and untreated wood samples were subjected to TGA in high purity nitrogen under a constant flow rate of $5 \mathrm{~mL} / \mathrm{min}$. Thermal decomposition of each sample occurred in a programmed temperature range of 30 to $200^{\circ} \mathrm{C}$. The continuous weight loss and temperature were recorded and analyzed to determine the following TGA parameters: thermal degradation rate ( $\%$ weight loss $/ \mathrm{min})$, initial degradation temperature and residual weight at $200^{\circ} \mathrm{C}$.

\section{Differential Scanning Calorimetry (DSC) Analysis}

Untreated and treated ground samples were analyzed using a Perkin Elmer thermal analyzer. All measurements were made under a $\mathrm{N}_{2}$ flow $(30 \mathrm{~mL} / \mathrm{min})$, keeping a constant heating rate of $10^{\circ} \mathrm{C} / \mathrm{min}$ and using an alumina crucible with a pinhole.

\section{RESULTS AND DISCUSSION}

\section{Weight Percentage Gain (WPG\%)}

The average weight percentage gain (WPG) of diazonium salt treated wood samples of jelutong, terbulan, batai, rubberwood, and pulai were $6,4.5,5.5,4$, and 5.3 respectively.

\section{Morphology Analysis}

Fourier Transform Infrared Spectroscopy (FTIR)

The formation of 2,6-diazo cellulose compound by the coupling reaction with diazonium salt and cellulose fiber was confirmed by the FTIR spectroscopic analysis of the untreated and treated wood, as shown in Fig. 3(a). The FTIR spectrum of the untreated wood clearly shows the absorption bands in the region of $3408 \mathrm{~cm}^{-1}, 2921 \mathrm{~cm}^{-1}$, and $1736 \mathrm{~cm}^{-1}$ due to $\mathrm{O}-\mathrm{H}$ stretching vibration, $\mathrm{C}-\mathrm{H}$ stretching vibration, and $\mathrm{C}=\mathrm{O}$ stretching vibration, respectively. These absorption bands are due to the hydroxyl group in cellulose, carbonyl group of acetyl ester in hemicellulose, and carbonyl aldehyde in lignin (Ismail et al. 2002). On the other hand, FTIR spectra of treated wood in Fig. 3(b) clearly show the presence of the characteristic band of NO group in the region of 1512 $\mathrm{cm}^{-1}$ and $1646 \mathrm{~cm}^{-1}$. The peaks at 1403 and $1457 \mathrm{~cm}^{-1}$ are due to the $-\mathrm{N}=\mathrm{N}-$ moiety of the azo compound, and the absorption band at $1309 \mathrm{~cm}^{-1}$ may be attributed to the symmetric deformations of $\mathrm{NO}_{2}$ presence in the cellulose azo compound (Elvy et al. 1995; Haque et al. 2009; Covolan et al. 1997). 


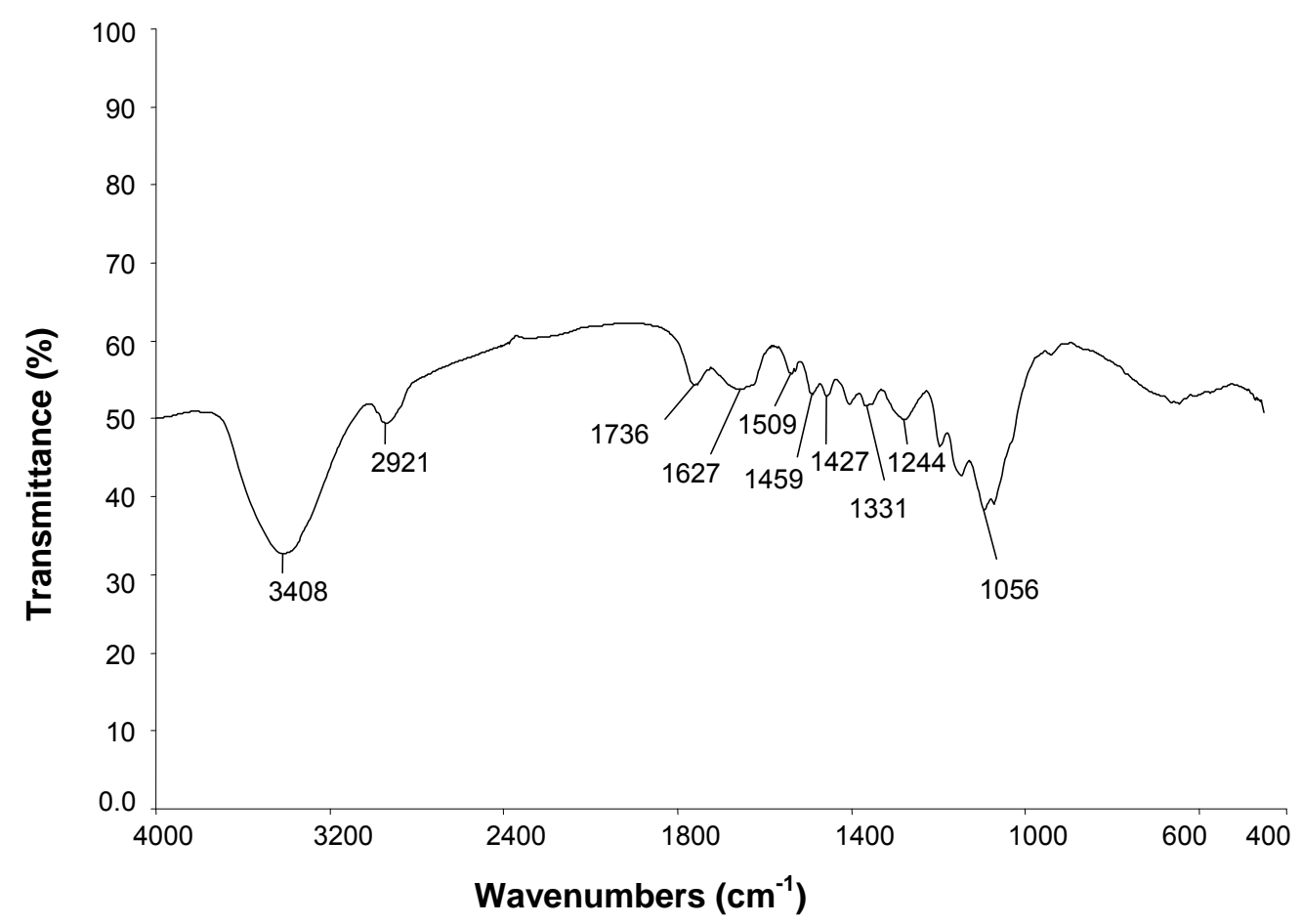

Fig. 3(a). FTIR spectra of untreated wood samples

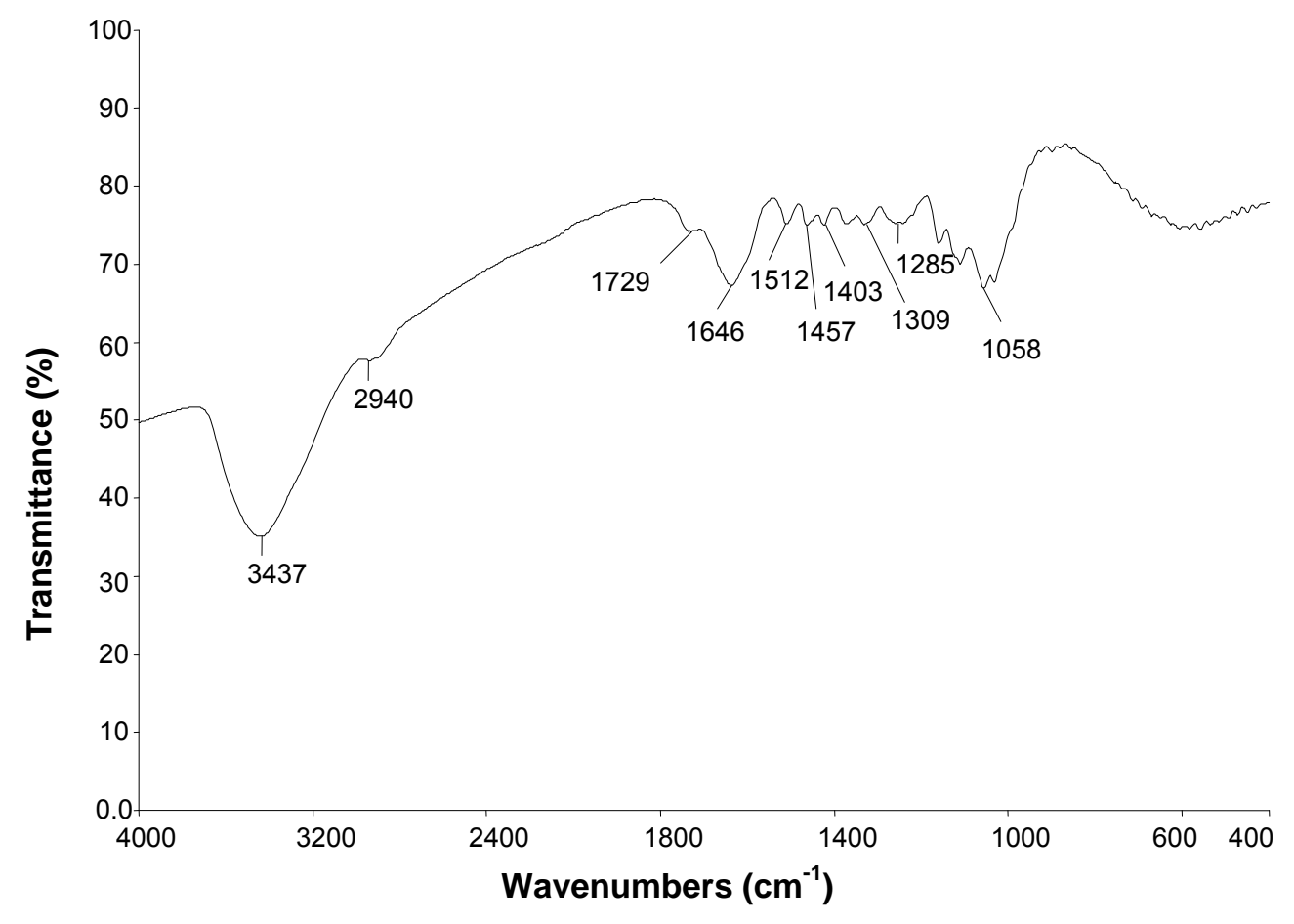

Fig. 3(b). FTIR spectra of treated wood samples 
The absorption band of $\mathrm{O}-\mathrm{H}$ group also shifted towards higher wave number $\left(3408 \mathrm{~cm}^{-1}\right.$ to $\left.3437 \mathrm{~cm}^{-1}\right)$ with narrowed band intensity, which gives further evidence of the reaction of cellulose hydroxyl groups with diazonium salt. Yields of 2,6-diazo cellulose can be explained as being due to the presence of three hydroxyl groups in the cellulose anhydroglucose unit. One is the primary hydroxyl group at $\mathrm{C}_{6}$, and the other two are secondary hydroxyl groups at $\mathrm{C}_{2}$ and $\mathrm{C}_{3}$. The primary hydroxyl group is more reactive than the secondary ones, and the coupling reaction at $\mathrm{C}_{2}$ and $\mathrm{C}_{6}$ results in the formation of 2,6-diazo cellulose.

\section{Scanning Electron Microscopy (SEM)}

In order to change the morphological properties of wood, all wood samples were chemically treated with benzene diazonium salt. The SEM images of untreated and treated wood samples are shown in Figs. 4(a) and 4(b) in transverse section.
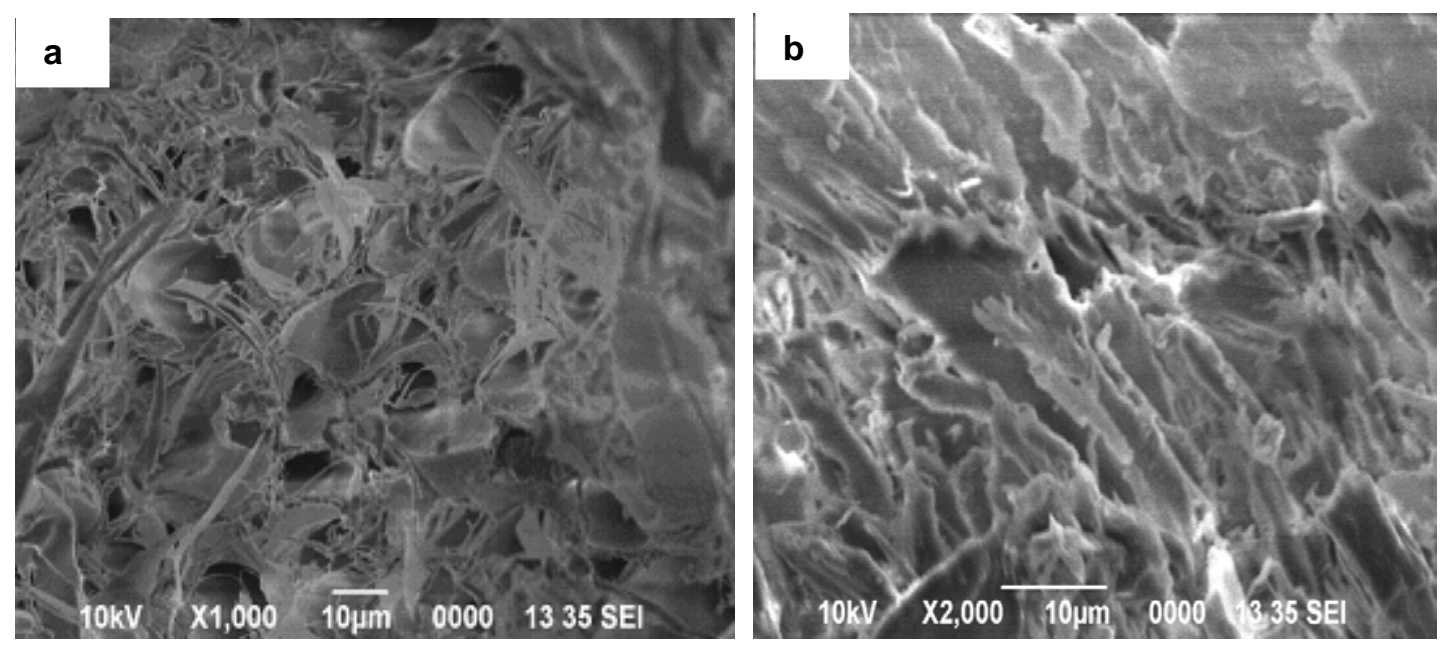

Fig. 4. Typical SEM micrographs of untreated (a) and treated (b) wood samples

The untreated wood in Fig. 4(a) clearly shows the number of void spaces and agglomeration of fiber in the wood surface, which could be removable by suitable chemical treatment (Sreekala et al. 2001; Zafeiropoulos et al. 2002). Figure 4(b) displays the micrograph of a treated wood sample. Comparing the images of untreated wood and treated wood reveals that the diazonium salts in the wood formed a rough coating and interaction on the fiber surface, which enhanced the morphological properties. Furthermore, diazonium salts treatment partially filled the void spaces of wood and aligns uneven fiber, which provided a smoother surface texture than raw wood. This result also suggests that the chemical reaction formed a strong interface with wood cell walls, accounting for the observed increase in mechanical and thermal properties.

\section{Dynamic Young's Modulus $\left(E_{d}\right)$}

The Dynamic Young's modulus $\left(E_{d}\right)$ of untreated and treated wood samples is given in Fig. 5. The $E_{d}$ for all treated wood samples was found to be higher than for untreated ones. The treated batai wood samples exhibited the highest percentage increase 
in $E_{d}(11.08 \%)$, followed by pulai $(7.13 \%)$, jelutong $(5.90 \%)$, terbulan $(5.18 \%)$, and rubberwood $(2.02 \%)$.

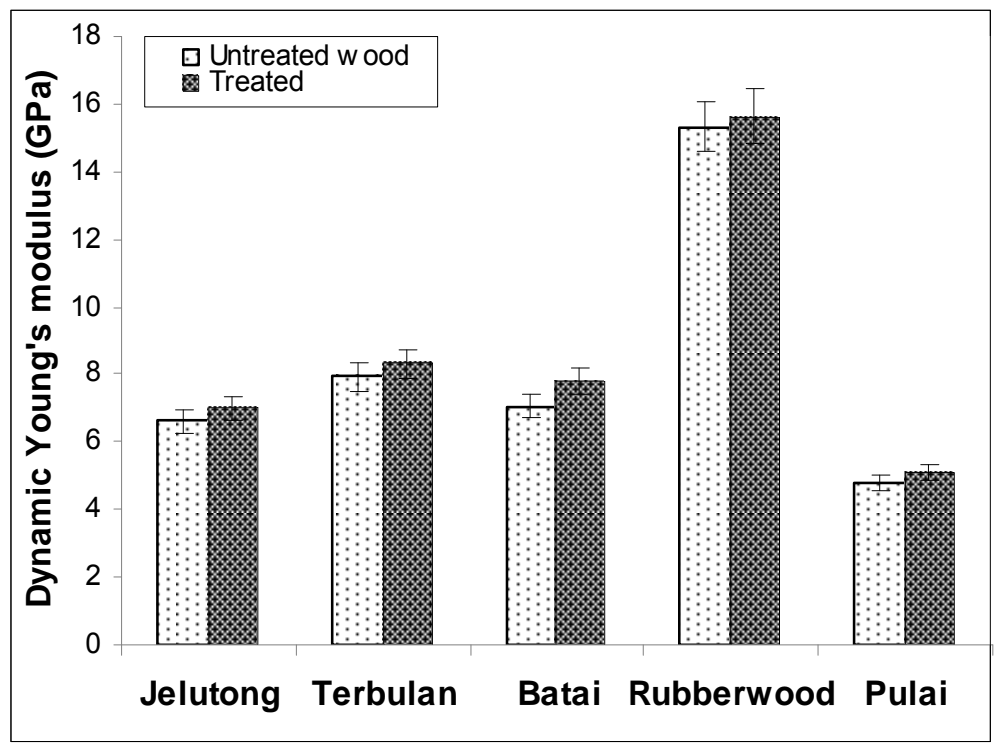

Fig. 5. Dynamic Young's modulus $\left(E_{d}\right)$ of untreated and treated wood samples

This result is expected, as the coupling reaction with cellulose in wood enhances the hydrophobic nature of wood and coating among wood fibers, improving Young's modulus. The higher $E_{d}$ in WPC seen in all species compared to untreated wood was due to the chemical modification, which is in accordance with other researchers (Yildiz et al. 2005; Minato et al. 1992). In the wood specimens, the coupling reagent reacts with $\mathrm{OH}$ groups of cellulose fiber to yield 2,6-azo compound as well as cellulose compound, thus enhancing the $E_{d}$ of the treated wood sample. However, for rubberwood, a small increase was found for treatment due to the high density of this species and the small amount of chemical incorporation inside the cell wall (Deka et al. 2002; Yap et al. 1990).

\section{Thermogravimetric Analysis (TGA)}

Figures 6(a-e) represent the TGA curves of untreated and treated wood samples. The results are summarized in Table 1. As seen in Figs. 6(a-e) and Table 1, the first weight loss between 60 and $100^{\circ} \mathrm{C}$ corresponds to the heat of vaporization of water in the sample. According to the literature, there is no degradation up to $160^{\circ} \mathrm{C}$ (Wielage et al. 1999). Above this, thermal stability gradually decreases, and decomposition takes place.

The thermogravimetric analysis of untreated wood and treated wood indicated that the initial weight loss started for both samples from $234^{\circ} \mathrm{C}$ to $265^{\circ} \mathrm{C}$. The coupling reaction improves the thermal stability of wood, with the initial and final decomposition temperature $\left(T_{i}, T_{f}\right)$ of all treated wood higher than that of untreated wood. The values of mass loss were observed to be higher in the case of untreated wood samples compared to those of treated ones, showing that the thermal stability of treated sample is higher. The major source of this stability is due to the coupling reaction with cellulose and new chemical bonding, which allows thermal energy to be distributed over many bonds (Ramiah 1976; Wielage et al. 1999). 


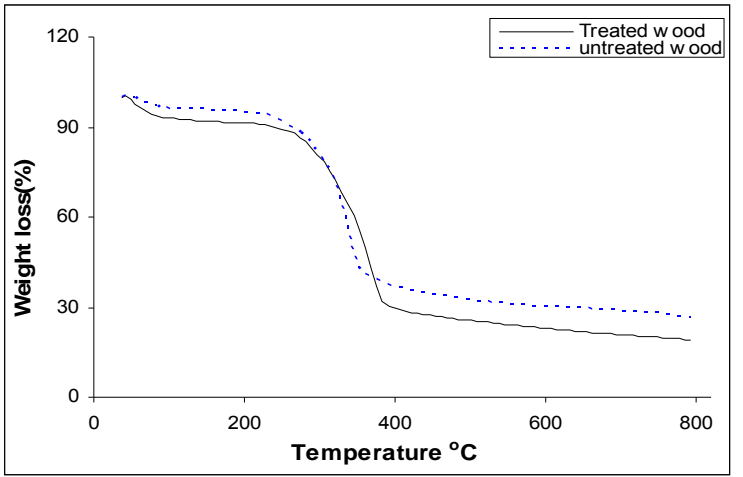

(a)

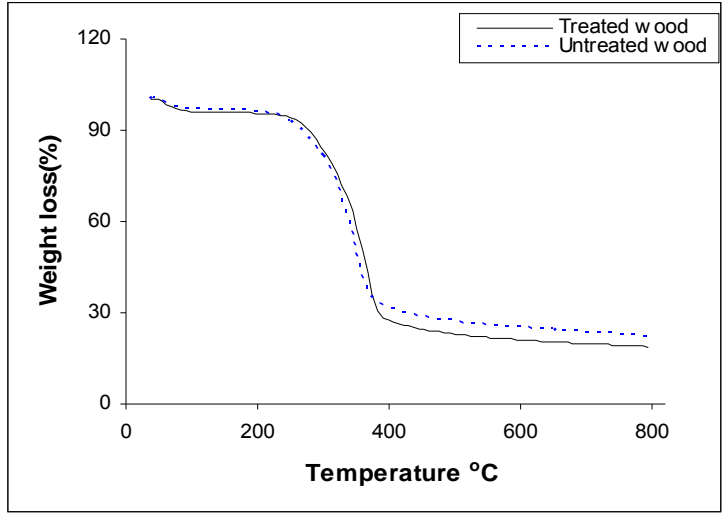

(c)

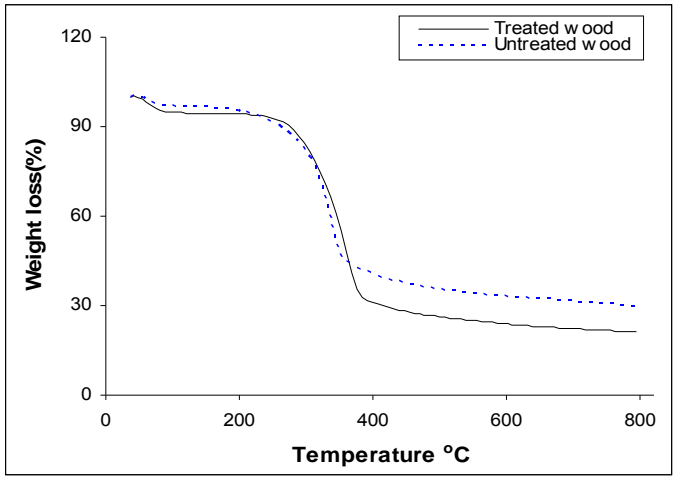

(b)

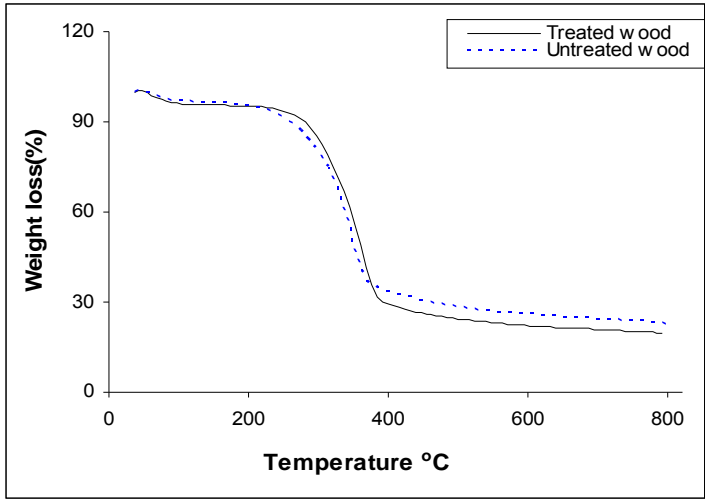

(d)

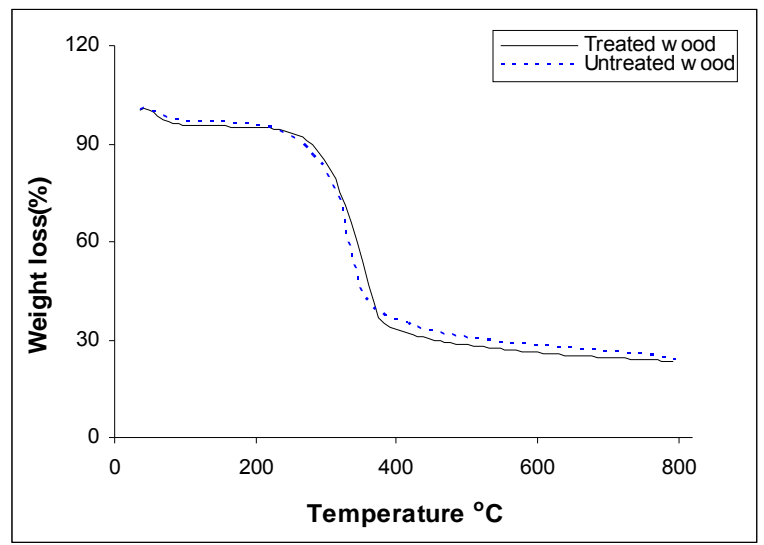

(e)

Fig. 6. TGA curves of untreated and treated wood species of (a) jelutong, (b) terbulan, (c) batai, (d) rubberwood, and (e) pulai

\section{Differential Scanning Calorimetry (DSC) Analysis}

The thermal stability of treated and untreated wood samples characterized by DSC is shown in figures $7(\mathrm{I}-\mathrm{V})$ and $8(\mathrm{I}-\mathrm{V})$ and important data (crystalline enthalpy and exotherm peaks) derived from these thermograms are summarized in Table 2. A broad endotherm observed in the temperature range approximately $50-150^{\circ} \mathrm{C}$ in both untreated and treated samples for all species indicates the presence of water molecules in the fibers. 
Table 1. Results of TGA Analysis of Untreated and Treated Wood Samples

\begin{tabular}{|l|l|l|l|l|l|l|l|}
\hline \multicolumn{2}{|c|}{$\begin{array}{c}\text { Wood species and sample } \\
\text { particulars }\end{array}$} & ${ }^{\mathrm{a}} T_{i}\left({ }^{\circ} \mathrm{C}\right)$ & ${ }^{\mathrm{b}} T_{m}\left({ }^{\circ} \mathrm{C}\right)$ & ${ }^{\mathrm{c}} T_{f}\left({ }^{\circ} \mathrm{C}\right)$ & ${ }^{\mathrm{d}} W_{T i}(\%)$ & ${ }^{\mathrm{e}} W_{T m}(\%)$ & ${ }^{\mathrm{f}} W_{T f}(\%)$ \\
\hline \multirow{3}{*}{ Jelutong } & Untreated & 242 & 383 & 359 & 89.96 & 32.11 & 28.63 \\
\cline { 2 - 8 } & Treated & 257 & 359 & 399 & 90.91 & 40.97 & 34.31 \\
\hline \multirow{3}{*}{ Terbulan } & Untreated & 250 & 375 & 360 & 91.34 & 35.46 & 30.52 \\
\cline { 2 - 8 } & Treated & 258 & 351 & 391 & 90.27 & 46.43 & 37.59 \\
\hline \multirow{3}{*}{ Batai } & Untreated & 234 & 406 & 367 & 94.60 & 27.00 & 26.50 \\
\cline { 2 - 8 } & Treated & 242 & 375 & 390 & 93.82 & 34.29 & 28.37 \\
\hline \multirow{2}{*}{ Pulai } & Untreated & 265 & 391 & 368 & 92.33 & 34.16 & 28.73 \\
\cline { 2 - 8 } & Treated & 273 & 367 & 398 & 86.92 & 37.07 & 30.12 \\
\cline { 2 - 8 } & Untreated & 257 & 391 & 360 & 92.88 & 33.88 & 33.22 \\
\cline { 2 - 8 } & Treated & 259 & 367 & 391 & 90.92 & 39.15 & 32.83 \\
\hline
\end{tabular}

${ }^{a}$ Temperature corresponding to the beginning of the decomposition

${ }^{\mathrm{b}}$ Temperature corresponding to the maximum rate of mass loss

${ }^{\mathrm{c}}$ Temperature corresponding to the ending of the decomposition

${ }^{\mathrm{d}, \mathrm{e}}$ and ${ }^{\mathrm{f}}$ mass loss at ${ }^{\mathrm{a}, \mathrm{b}}$ and ${ }^{\mathrm{c}}$

Generally, decomposition starts for wood fiber (cellulose, hemicelluloses and lignin) at temperatures around $200^{\circ} \mathrm{C}$ to $360^{\circ} \mathrm{C}$ (Lee et al. 2006; George et al. 2000). Therefore, the second endothermic peaks, which were higher than $200^{\circ} \mathrm{C}$, indicate the decomposition temperatures of the wood fibers. As one can see from the Figs. 7 and 8 and Table 2, the first decomposition temperature of all treated wood samples exhibited a higher value than the untreated wood samples, indicating that treated sample is more thermally stable (Lee et al. 2008).

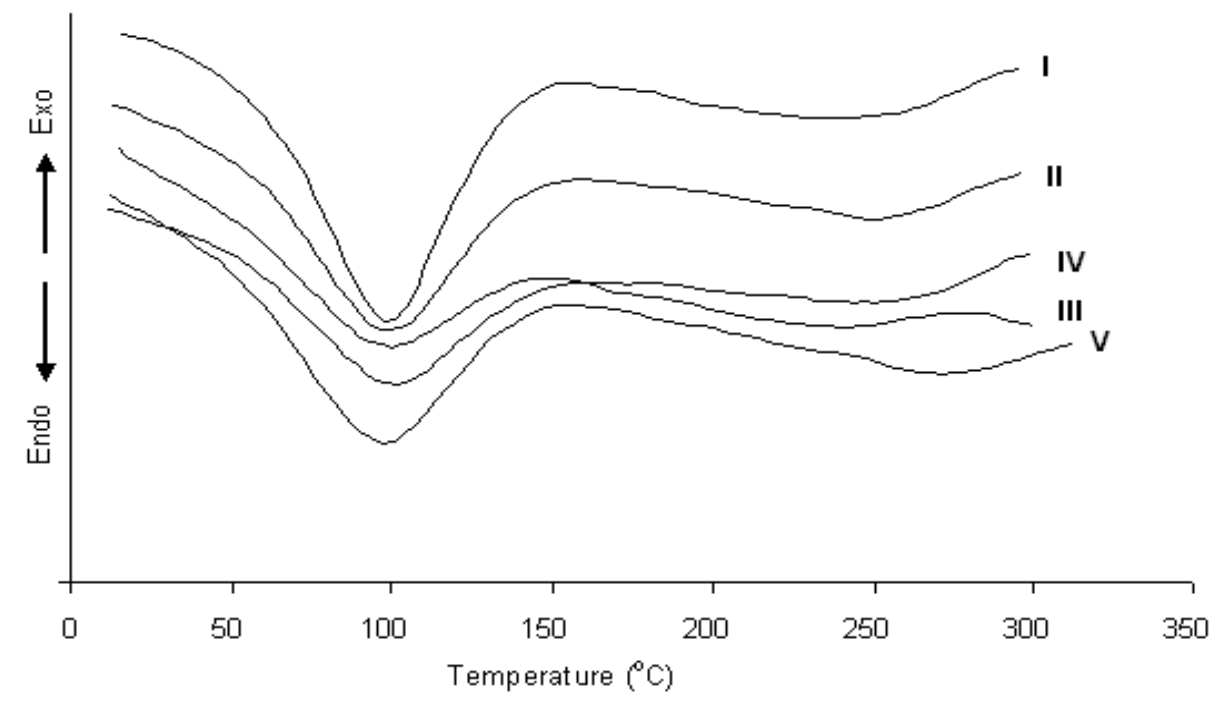

Fig. 7. DSC thermograms of jelutong (I), terbulan (II), batai (III), rubberwood (IV), and pulai (V) untreated wood samples 


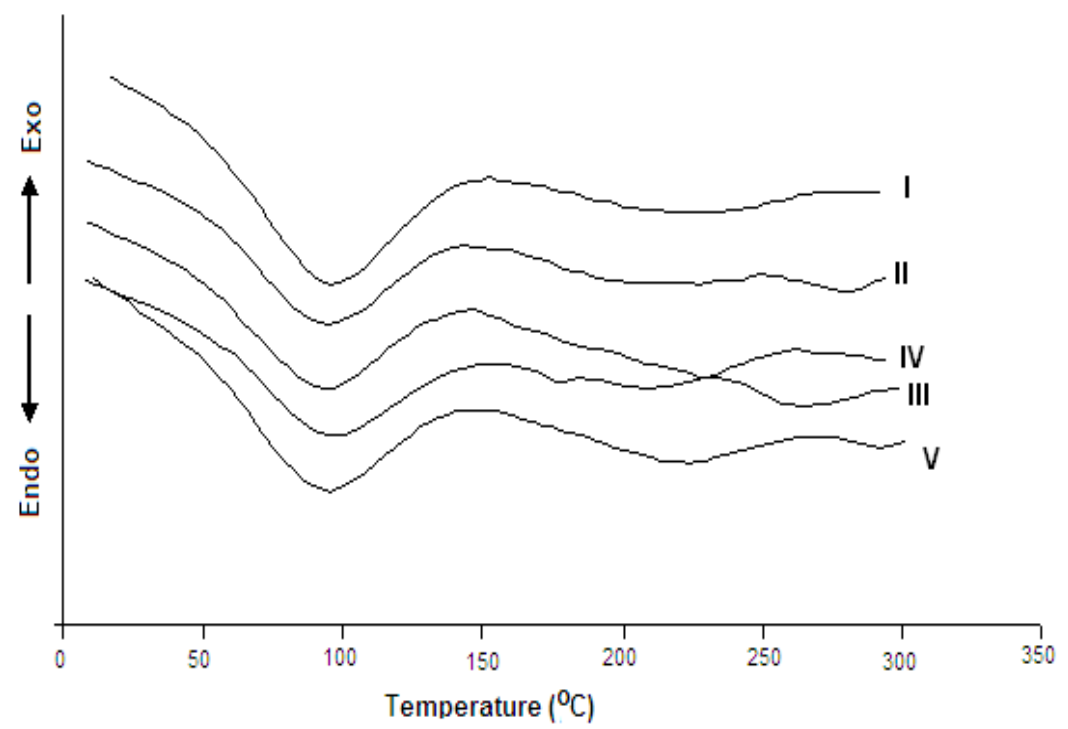

Fig. 8. DSC thermograms of jelutong (I), terbulan (II), batai (III), rubberwood (IV), and pulai (V) treated wood samples

Table 2. Results of DSC Analysis of Untreated and Treated Wood Samples

\begin{tabular}{|l|l|c|c|}
\hline Wood species & Sample particulars & $1^{\text {st }}$ Exotherm peaks $\left[^{\circ} \mathrm{C}\right]$ & $\begin{array}{c}\text { Crystallization Enthalpy“, } \\
-\Delta \mathrm{H}(\mathrm{J} / \mathrm{gm})\end{array}$ \\
\hline \multirow{3}{*}{ Jelutong } & Untreated & 154.89 & 191.12 \\
\cline { 2 - 4 } & Treated & 158.08 & 287.24 \\
\hline \multirow{3}{*}{ Terbulan } & Untreated & 161.15 & 155.11 \\
\cline { 2 - 4 } & Treated & 164.38 & 270.24 \\
\hline \multirow{3}{*}{ Batai } & Untreated & 148.57 & 184.39 \\
\cline { 2 - 4 } & Treated & 154.89 & 204.10 \\
\hline \multirow{3}{*}{ Rubberwood } & Untreated & 158.05 & 151.82 \\
\cline { 2 - 4 } & Treated & 167.55 & 207.42 \\
\hline \multirow{3}{*}{ Pulai } & Untreated & 151.75 & 203.11 \\
\cline { 2 - 4 } & Treated & 158.07 & 260.35 \\
\hline
\end{tabular}

The crystallization enthalpy $(-\Delta H)$ of all treated wood samples was higher than that of untreated samples. As the coupling reaction took place inside wood, the $-\Delta H$ increased (Table 2). Since the yielded 2, 6-diazo cellulose compound in wood interfered with crystallization, it is assumed that the increase of $-\Delta H$ was closely related to the inecrease of crystal size of cellulose itself (Hamdan et al. 2010). 


\section{CONCLUSIONS}

From the present study, it is concluded that the dynamic Young's modulus $\left(E_{d}\right)$, thermal properties, and morphological properties of all the selected tropical wood species were greatly improved by the benzene diazonium salt treatment. Diazonium salt performed a coupling reaction with cellulose in wood species and yielded 2,6-diazo cellulose compound, as confirmed through FTIR spectral analysis, where the characteristic peaks at 1403 and $1457 \mathrm{~cm}^{-1}$ were obtained due to the $-\mathrm{N}=\mathrm{N}$ - moiety of the azo compound. The Scanning Electron Microscopy (SEM) of treated wood showed a smoother surface texture than the raw wood species. The treatment increased the $E_{d}$ by $2.02-11.08 \%$ at $4-6 \%$ WPG. Chemical modification with diazonium salt of wood species made it thermally more stable over certain temperature ranges during this study. The TGA and DSC analyses revealed that decomposition temperature and exotherm peaks increased after treatment. The authors propose that all tropical light hardwoods used in this research are suitable for the coupling reaction which increases mechanical, thermal and morphological properties.

\section{REFERENCES CITED}

Brelid, P. L., Simonson, R., Bregman, O., and Nilsson, T. (2000). "Resistance of acetylated wood to biological degradation," Holz als Roh und Werkstoff. 58, 331-337.

Chao, W. Y., and Lee, A. W. (2003). "Properties of southern pine wood impregnated with styrene," Holzforschung 57, 333-336.

Covolan, V. L., Innocentini, M. L. H., and Rossi, C. L. (1997). "Chemical modifications on polystyrene latex: Preparation and characterization for use in immunological applications," Advance Polym. Technol. 8, 44-50.

Deka, M., Saikia, C. N., and Baruah, K. K. (2002). "Studies on thermal degradation and termite resistant properties of chemically modified wood," Bioresource Technol. 84, 151-157.

Elvy, S. B., Dennis, G. R., and Ng, L. T. (1995). "Effect of coupling agent on the physical properties of wood-polymer composites," J. Mat. Proc. Technol. 48, 365-372.

Galpperin, A. S., Kuleshov, G. G., Tarashkevich, V. I., and Smtov, G. M. (1995). "Manufacturing and properties of modified wood: A review of 25 years work," Holzforschung 49, 45-50.

Hill, C. A. S. (2006). "Chemical modification of wood," In: Wood Modification: Chemical, Thermal and Other Processes, John Wiley \& Sons Ltd, 45-99.

Hartley, I. D., and Schxeider, M. H. (1993). "Water vapour diffusion and absorption characteristics of sugar maple (Acer saccharum, Marsh.) wood polymer composites," Wood Sci. and Technol. 27, 421-427.

Haque, M. M., Hasan, M., Islam, M. S., and Ali, M. E. (2009). "Physico-mechanical properties of chemically treated palm and coir fiber reinforced polypropylene composites," Bioresource Technol. 100, 4903-4906.

Holyle, R. J., and Woeste, F. E. (1989). Wood Technology in the Design of Structure, Iowa State University Press, USA, $5^{\text {th }}$ Edition. 
Halabe, U. B. Bidigalu, G. M. Ganga Rao, H.V.S., and Ross, R. J. (1995).

"Nondestructive evaluation of green wood using stress wave and transverse vibration techniques," Mater. Eval. 55(9), 1013-1018.

Hamdan, S., Talib, Z. A., Rahman, M. R., Ahmed, A. S., and Islam, M. S. (2010). "Dynamic Young's modulus measurement of treated and post-treated tropical wood polymer composites (WPC)," BioResources 5(1), 324-342.

Hamdan, S., Rahman, M. R., Ahmed, A. B., Talib, Z. A., Islam, M.S (2010). Influence of N, N-Dimethylacetamid on the thermal and mechanical properties of wood polymer composites (WPC). BioResources 5(4), 2611-2624.

Ismail, H., Edyhan, M., and Wirjosentono, B. (2002). "Bamboo fiber filled natural rubbercomposites; The effects of filler loading and bonding agent," J. of Polym. Test. 21(2), 139-144.

Ibrahim, M. (2002). "Preparation of cellulose and cellulose derivative azo compounds," Cellulose 9, 337-349.

Islam, M. S., Hamdan, S., Rahman, M. R., Jusoh, I., and Ibrahim, N. F. (2010). "Dynamic Young's modulus and dimensional stability of Batai tropical wood impregnated with polyvinyl alcohol," J. Sci. Res. 2(2), 227-236.

Kumar, S. (1994). "Chemical modification of wood," Wood Fiber Sci. 26(2), 270-280.

Lee, S. Y., Doh, G. H., and Kang, I. A. (2006). "Thermal behavior of hwangto and wood flour reinforced high density polyethylene (HDPE) composites," Mokchae Konghak 34, 59-66.

Lee, S. Y., Kang, I. A., Doh, G. H., Kim, W. J., Kim, J. S., Yoon, H.G., and Wu, Q. (2008). "Thermal, mechanical and morphological properties of polypropylene/clay/ wood flour nanocomposites," eXPRESS Polym. Lett. 2(2), 78-87.

Minato, K., Yusuf, S., Imamura, Y., and Takahasi, M. (1992). "Resistance of formaldehyde treated wood to biological attack," Mokuzai Gakkaishi 38, 1050-1056.

Rowell, R. M. (2005). "Chemical modification of wood," In: Handbook of Wood Chemistry and Wood Composite, Rowell, R. M. (ed.), Taylor and Francis, CRC Press, 381-420.

Rowell, R. M. (2006). "Chemical modification of wood: A short review," Wood Mater. Sci. Eng. 1, 29-33.

Rahman, M. R., Haque, M. M., Islam, M. N., Hasan, M. (2009). "Mechanical properties of polypropylene composites reinforced with chemically treated abaca," Composites: Part A 40, 511-517.

Ramiah, M. V. (1976). "Thermogravimetric and differential thermal analysis of cellulose hemicelluloses and lignin," J. Appl. Polym. Sci. 14, 1323-1337.

Schneider, M. H. (1994). "Wood polymer composites," Wood Fib. Sci. 26(1), 142-151.

Sreekala, M. S., Kumaran, M. G., and Thomas, S.(2001). "Stress relaxation behaviour in oil palm fibres," Mat. Lett. 50(4), 263-273.

Wielage, B., Lampke, Th., Mark, G., Nestler, K., and Starke, D. (1999). "Thermogravimetric and differential scanning calorimetric analysis of natural fibers and polypropylene," Thermochim. Acta 337, 169-177.

Yap, M. G. S., Chia, L. H. L., and Teoh, S. H. (1990). "Wood polymer composites from some tropical hardwoods," J. Wood Chem. Technol. 10(1), 1-19. 
Yalinkilic, M. K., Imamura, Y., Takahashi, M., Demirci, Z., and Yalinkilic, A. C. (1999). "Biological, mechanical, and thermal properties of compressed-wood polymer composite (CWPC) pretreated with boric acid," Wood Fib. Sci. 31(2), 151-163.

Yildiz, U. C., Yildiz, S., and Gezer, E. D. (2005). "Mechanical properties and decay resistance of wood polymer composites prepared from fast growing species in Turkey," Bioresource Technol. 96, 1003-1011.

Zafeiropoulos, N. E., Williams, D. R., Baillie, C. A., and Matthews, F. L. (2002). "Engineering and characterization of the interface in flax fibre/polypropylene composite materials Part I: Development and investigation of surface treatments," Composites Part A 33(8), 1083-1093.

Article submitted: September 27, 2010; Peer review completed: October 19, 2010; Revised version received: December 28, 2010; Accepted: January 15, 2011; Published: January 18, 2011. 